\title{
Education, the Formation of Personality and the Destiny of a Man
}

\author{
Vladimir Puzikov \\ Omsk State Pedagogical University \\ Omsk Humanitarian Academy \\ Omsk, Russia \\ puzikov@omgpu.ru
}

\begin{abstract}
Education - is the process of the personality formation based on the assimilation of information knowledge, skills, values and meaning, the experience of socio-cultural practices and professional competences. Education as a science is the power by which latent potentialities and possibilities of man are awaken and then transformed into his ability. Education builds not only the social reality, but also determines events and human actions, his path of life and destiny.
\end{abstract}

Keywords - education, information, knowledge, values, experiences, abilities, personality, destiny of man.

\section{INTRODUCTION}

Education as a process of training and upbringing, professionalization and socialization is a projection of what is happening in the society. The education is a reflection of the society, the society is a reflection of the education. That is why, for a long time now, a search for a new more effective configuration of the relationship between the system - society and its subsystem - education has been conducted, on both global and a national scales. The article discusses the reference points of their contact, the points of growth, the "pulling" factors of development, the change of system combinations of interaction of education with other subsystems of society. Various sets of their combinations are considered and proposed, the chain of their data is extended, priorities are changed. And, all this is closely interconnected and intertwined in an "Ariadne's ball of string», which is to be unraveled in spite of the difficulties. That will certainly help both the society, and the education, and a student to successfully get out of the tangled maze of joint problems.

In the process of education, the cognizing subject not only masters general educational and special-professional knowledge, but influenced by the prolonged contribution of the acquired knowledge on the formation of the personality during the whole period of life.

Basically, education is the dominant factor determining the entire subsequent destiny of a man. Fate is the path of destined, and sometimes inevitable, events and actions in a person's life. But with the help of education we can correct the life path of a man, and therefore, make adjustments to his fate.

\section{EASE OF USE}

As is known the Russian word "education" includes a reminder of the "image" - Greek "paideia" means bringing something to a certain form. What is usually understood by "education"? Experience shows that this term is of different semantic significance. A.V. Lunacharsky noted in the speech "What is education?" - when the society had to determine what a man should represent of himself and what the society should make of him, they got a an image of a human creation from some material» [4]. In the context, Lunacharsky used the term "education" as equivalent to both terms "upbringing" and "learning". F. Mahlup understood education as a process of learning, knowledge acquiring, including those from educational institution, industrial training, education through television, in the family, education in the church, training in the armed forces, self-education based on self experience [7]. At the same time, education can be understood as a process or a product of the mind formation, individual qualities, character and abilities of a person oriented to some ideal images or specific social standards. The issue of education reflects the tendency to change paradigms - the notion of the role of education in the life of society and the fate of a man. Questions arise: How does the process of education occur? What kinds and forms of knowledge and cognition determine the path to being an educated person? Education is presented as ideal, perfect, and it creates individually unique forms, the image and character of a man. It is in these parameters that a person's free activity, based on spirituality and humanity, embedded, potentially encoded, but not disclosed, takes place. A person's life is the realization of spirituality, a movement towards humanity, the transformation of one's own nature and the soul through education. Education as something ideal is a "culture of a soul", "inspiration" of material human nature. It is the ever new and growing formation of man, the acquisition of his own «self» from the universal. This is an initial alienation into an ideal world, this is the "microcosm" of reality, the individual-personal center of man. Education is endless, it can not be "started and finished" - it is a category of being, an "aura" in which the human essence exists.

It is impossible to impose "education" from outside. The only possibility is an immanent transformation of objective knowledge coming from outside into a spiritual-activity state. 
In the history of education, there are two main trends in understanding the essence of education. The first trend is due to the accentuation of the individual-personal aspect of education. Education is understood as the cultivation of inclinations, as the unfolding formation of already existing natural aptitudes. The second tendency is connected with the comprehension of orientation toward the universal. A single individual is regarded as a special case of the general concept of "man."

Modern interpretation of education is impossible, both without the identification of universal essential characteristics, and without those special, which are specific for this particular level of development. The universality of education is manifested in the fact that it implies the assimilation of a certain amount of knowledge, skills and abilities. It is quite right to consider education as an appropriately organized process of learning and socialization of the individual, and as self-education, that is, an individual process of purposeful selfdevelopment. The penetrating power of education, that creates an image (personality) and the destiny of man is directly embedded in the transformation of his natural inclinations into his abilities. Education is a function of the subject, which correlates with the individual life path, particularities of passing crisis points of bifurcation development, is determined by socio-cultural experience and historical traditions of society.

The natural inclinations and abilities of a person are important, but not the dominant factors that determine the formation of a person. Potential abilities and predispositions of the individual can be realized, become not only possible, but also valid in the presence of sufficient and favorable social conditions. And in this sense, the formation of the personality and the destiny of a man largely depend on the education system, which forms its values and semantic orientations.

Fate is one of the oldest phenomena and key words of culture, which, despite changing ideas about the world, as well as changes in the world itself and in man himself, remain in language and culture. On the one hand, fate is knowledge, the concept of predetermination, the conditioning and the inevitability of events and actions in human life. On the other hand, man is the creator of his own destiny, his future everything that will happen to him. Man - is the only natural beings that has a conscience, and is able to listen to the voice of the moral law. That is why, as a participant of history, man can not completely absolve himself of responsibility for unrealized creative opportunities, for neglecting his destiny. Fate is a way of self-identification of an individual, therefore man is intent on its studies and self-knowledge. Man can not give up attempts to smooth out the contradiction between the "temptation" to go with the flow of fate and the desire for freedom and self-affirmation. At the same time, the fate reflects the experience of comprehending the categories of freedom and necessity regarding human existence, in which the human mind sees the foundations of life and power that control history and society.

Man has always strived to make the world comprehensible and meaningful, to fill with semantic content his own being. As a part of the relations created by society, man could not help noticing their historical variability, and then a question arose about the direction and sense of these relations for the individual, about the place of the individual in the historical process and about its fate. The subject of the interaction of man and society is either explicitly or implicitly presents in any discourse. These two closely interrelated parts can not exist without each other. They exist in reality only as two moments within the historical process, which is something third in their dialectic. It also means that both moments include each other on each segment of their being and developing, and that the mediate field for this is the aforementioned "third" moment" [3, p.249]. The meaning of human destiny is expressed as the social significance of individual existence, as its essence, included in the context of socio-historical transformations.

The study of human destiny remains important and significant regardless of the political system and socio-cultural situation. And in the third millennium, the existence of man correlates with a whole series of issues, from the solution of which depends the future of civilization, its survival. The range of issues include: humanity and spirituality, meaning and purpose of life. The processes of globalization on the planet Earth, associated with the uncontrolled development of manmade civilization, information technologies and wars, with dynamism in the telecommunications sphere, have increasingly dominating influence on man. Acts of terrorism, armed conflicts and civil wars, taking away many human lives, a sense of constant threat and insecurity, a fear of the future, which may not exist, all this inevitably causes changes in the individual and public consciousness. In the conditions of instability, chaos and "lack of ideology" of postmodern society, a person feels a constant alarm for the future.

One of the main postmodern man's installations (a vivid example is the "post-Soviet man") - to live today, without trying to look into the distant future. Man is no longer the master of his own destiny, as his life depends on the situation, his opportunities, luck, well-established circumstances. Coming from the West the universal passion for pranks, lotteries, roulettes, all kinds of television shows, color revolutions, accompanied by the overthrow of political regimes and legitimate governments, humanitarian catastrophes that tempted the destiny of man and whole nations. A man "rushing headlong" deep into the game, distracting himself from the heavy thoughts of building his future. That is why the urgency of this approach to the problem of human destiny increases.

Mass consciousness is infected with illusions that are widely spread in its bosom of esotericism and mysticism. The displacement of truth from culture is carried out on the basis of ontologization of "likeness". The danger is that the coming era might has neither truth of God nor the truth of Man. Discoveries in the field of genetic engineering, cloning experiments raised the question of the value of death as the meaning of the assuming beginning of life. Man began to claim "the place of God," because he learned to control not only the process of birth, but also learns to "control death." On the other hand, man is the only natural creature with conscience that can listen to the voice of the moral categorical imperative. Each epoch, proceeding from its inherent culture, leaves its imprint on the content of categories and their understanding as objects of analysis. The peculiarity of the idea of destiny lies in the fact that it touches upon the most general worldview principles and 
orientations inherent in this or that society and culture, including spheres of personal, national, confessional life. A certain attitude towards the ideas about the destiny of man is connected with the cultural tradition of the people, and is generated by the specifics of the historical conditions of its existence. Through the disclosure of the concept of fate, the idea of a person that is the subject and object of sociocultural processes can be recreated. Thanks to which the study of the concept of fate in this or that period of human development allows us to identify stereotypes of human behavior, its relation to the surrounding reality, and the assessment of its own strengths and capabilities. Thus, the very attitude to fate appears as one of the important characteristics of the type of personality formed by one or another circumstance.

The complexity of the scientific development of the issue of the fate of man is determined by its discussion and the absence of generally accepted interpretations. This is due to the lack of elaboration of the concept, which stimulates the need for a special study. In which education, the formation of personality and the destiny of a person are considered as three constituent parts of a single and inextricable process of interaction and mutual influence. The need for a scientific analysis of the available knowledge about the fate of a person and its consideration in a changing socio-historical context is comprehended and transformed into a question of understanding the meaning of human destiny.

Man has always tried to discover the mystery of the forces of nature that affect him, the action of which he explained by the presence of a certain fate, karma or fortune. Many researchers have for centuries linked this to the refusal of the ancient people to recognize the fact that the power of destiny occurs at a time when people first realize that they can not control the natural forces by their own will and that they are all equally subject to these forces (Homer). Homer's concept of fate remains the most meaningful of the known representations of the past to this day.

Historically, ideas about fate arise in connection with religious beliefs, with the belief of a person in the otherworldly, supernatural world. Throughout life, each person thinks about the purpose and meaning of life, about the role that is given to him. In philosophy and the history of culture, fate is represented by myths, forecasts, symbolic signs, ritual actions, fortune-telling, ethnic perceptions and in all forms of worldview. Fate lives in a collective and individual consciousness.

In the history of philosophical thought, fate appears incomprehensible to man by the predetermination of actions and events. Some aspects of the discussion of this issue are found in the writings of ancient philosophers, who identified two issues. The first one: is fate given to man by gods or is it a consequence of the laws of nature? The second one: how to connect the fate and will of man?

In the Christian theology of the Middle Ages, there was a doctrine of fate, which was interpreted in the form of divine revelation and versatile activity of people.
Humanists philosophers represented fate as fortune in the aspect of chance. At the same time, Man was elevated to the status of a creator and defined as the creator of his life path.

Ideas of the Enlightenment and the philosophy of G.V.F. Hegel contributed to the birth of a concept in which the destiny of mankind was determined by the stage of the development of the world spirit.

The key question of Russian philosophy that relates to fate is the question of evil, which is refracted through the prism of philosophical and historical concepts. So, Alexei Fyodorovich Losev represented destiny as the life-meaning concept of culture, that reflected human being.

The issue of fate is the subject of interdisciplinary research by Soviet scientists, considered in various aspects: historical, cultural, pedagogical, psychological, religious, sociological, aesthetic, and philosophical. Soviet philosophers of the second half of the 20th century interpreted the term "destiny" as an existential, which did not receive the status of a philosophical category, was used as a metaphor, a synonymous to the line of life. A few monographs, dissertations, and articles are devoted to "Fate" as a phenomenon

In fact, at the present stage of the development of pedagogical and philosophical thought, the problem of fate has not been adequately comprehended. In this connection, it seems to us that it is absolutely necessary to carry out research in which is supposed to stop looking at the meaning of understanding of human destiny, considered in conditions of social transformations and in the historical context of globalization.

The processes of globalization caused a "long list" of the world's global problems. The most significant ones are: violence, ecological crisis and alienation. Foreign researchers: R. Attfield, K. Ineda, X. Rolston, L. White and others are trying to determine the historical and socio-cultural origins of the imbalance between man and nature. These problems are inextricably linked in their origin by the phenomenon of alienation. At present, it is obvious and probable that there is insufficient research, in which the issue of alienation is studied in a comprehensive, multidimensional way and in the logic of development.

The same is with the study on the topic of the fate of man and the meaning of life. Fundamental studies in this area are practically absent. It seems that one of the main reasons for this situation - a limited number of studies is not the lack of research interest in the topic of human destiny, but a limited choice of knowledge tools: theories, approaches, methods.

The emergence of new research approaches in the post-nonclassical stage of the development of science may lead to a change in understanding of human destiny. In particular, the use of the synergetic approach, where a person is viewed as a nonlinear, open, dissipative structure, as a self-organized system, expands the research tools that create new opportunities for explaining the secrets of human nature, penetrating its deep roots. The synergetic approach, to some extent, being a prerequisite and condition for the expansion of the horizon of knowledge, allows us to look differently at the fate of man. At the same time, this approach has limited 
explanatory possibilities, which does not allow to form conceptual notions about destiny.

"Destiny, in spite of the change in the person's ideas about himself, about the world he exists in, is comprehended, first of all, in two directions. On the one hand, destiny is the concept of predetermination, conditionality, the inevitability of events and actions that determine the existence of man. On the other hand, the person is the smith of his own fortune and the creator of his destiny, of his future - of what will happen, what will happen to him "[10, p.34]. Meanwhile, there is experience of a philosophical understanding of freedom and necessity in human destiny applied to the social being, where the mind sees the mechanisms that govern individual existence.

During a long period of lonely life and in the absence of society, a person makes attempts to clarify the unknown, to fill with semantic content his own individual being. However, it is not possible to carry out this plan in a solitude. It is necessary to go beyond the limits of individual existence through communication, establishing contacts and relationships with other individuals. As a result, this output forms a set of interacting people - society, social being. In reality, man and society do not exist momentarily and polarly, but permanently and integrally as a kind of a connecting link, called "social", that emerges as a result of interaction, in various forms that characterize social being, manifested in the sociocultural context of permanent changes. A man creates the destiny of society, and society creates the destiny of man.

The role of society in the process of personality is in the fact that every individual during socialization assimilates those norms and principles of the given society. Relations between society and the individual, being one of the central problems of all the human sciences, generate some type of sociality. The great thinkers of the 19th century, Karl Marx and Friedrich Engels, in a long series of their outstanding works addressing the theme of education, upbringing and personality formation, analyzed various historically established types of society, which enabled them to distinguish different types of sociality. The first type of sociality is a relationship of personal dependence, when the individual totally depends on the society in which he lives. Since outside the interacting set of people an individual can not survive physically, only joint activity ensures his existence (primitive society). The second type of sociality is a relationship of property dependence, which is characterized by a universal exchange of goods (capitalist society). And the third type of sociality is a free individuality based on the universal development of individuals and the realization of the potential abilities of each individual (communist society) [7].

From the point of view of creating the necessary social conditions in modern society for the formation of creative activity of students, the latter type of sociality retains its relevance as the ideal of the relationship between society and an individual. Creation of conditions encouraging the disclosure of the creative forces of each individual becomes an indispensable condition for the development of everybody, and is the expected goal to which every society aspires. In this regard, the following questions become important: What ideas and values dominate in society and education? What is the extent of their distribution among children and young people? What are the consequences of their impact on the process of forming a creative personality? In particular, K. Manheim in connection with the issue of values and their influence on the process of personality formation, distinguished two extremes, which adversely affect public development. The first is the anarchy of values, when everyone lives only according to their own attitudes. The second is the regulation of all aspects of human life [6, p. 85]. As a consequence, it forms an individual consciousness that has a direct negative impact on the process of the formation of public consciousness.

Accumulating anxiety about tomorrow leads a man to total fear for his future. An effective means against such fear is education, which is designed to educate independently thinking and self-confident people. To propagate these or other norms of life, all possible means, which are in the hands of the ruling elite of society, are used. Thus, public consciousness, which has a direct impact on the process of the formation of individual consciousness, is formed. As a result, an educated man becomes not only the owner of objective knowledge of the world around him, but also the owner of a sense of responsibility and empathy for everything that happens in society. Together with knowledge in the process of education and upbringing (education), a person not only penetrates into the secrets of the universe, but also in the treasury of human culture. As a result, education is the main determinant of social development.

Intuitively, at the level of common sense, wise people from the priests of the Ancient East and Confucius to Lomonosov and Hegel understood that the destinies of peoples depend to a great extent on how much the state cares about the education system and how it is used. Moreover, in modern conditions the fateful role of this system has immeasurably increased. What was done in previous times with the help of heredity, family and folk traditions, can now be achieved only through education. Enlighteners from Voltaire and Radishchev to Feuerbach, absolutizing the importance of the sphere of education, regarded it as the main cause of social change. However, all of them found themselves in a closed logical circle: on the one hand, they proceeded from the assumption that the individual, his ideas and moral qualities are the product of the environment, circumstances, and, therefore, that people correspond the purpose of man, human circumstances must be made humane.

At the same time, the unconditional categorical imperative and a good sign of our time is the influential role of education on the destiny of the country in general, and the fate of an individual, in particular. The old theoretical and methodological question: is education doomed to be only a "secondary reflection" of society, the level of its technological, economic and socio-political development, or is it capable of a relatively independent and very significant factor of progress, largely determining the historical destinies of states and humanity? (In this regard, it is extremely important to identify the potential for the impact of education on the fate of the world and the fate of a particular person.) In connection with the question posed, it is extremely important to identify the potential for educational impact on the fate of the world and the fate of a particular person. 
A well-known fact is the increasing role of the education system in the process of personality formation. What was done in previous times with the help of heredity, traditions, family and national customs, can now be achieved through education. As a result, the importance of the sphere of education is absolutized and regarded as the main cause of social change, social progress. The answer to the question of the possibility of the education system to change people's consciousness at first glance is obvious. Under the conditions of todays life, almost everyone, being a part of that system for many years, is convinced on his own long term experience that consciousness is greatly expanded by informational discoveries, new ideas, developing of abilities, skills and knowledge. As is known, sensually perceived phenomena may not coincide with the essence of the subject and even contradict it. Ignoring this fact is fraught with errors and gross mistakes. A.G. Asmolov writes: "How can one not understand that education, consciousness determines all our being, shape our souls" [1]. In this statement, there is not only the unilateral exaggeration of the visible, but two mixed questions. The first is the relation of consciousness to being, which is the fundamental question of philosophy. In this case, A.G. Asmolov has the standpoint of subjective idealism: opinions rule the world.

Meanwhile, people's consciousness is determined, by their being - the historical way of producing the means of life and life itself, while consciousness, having relative independence and specific laws of development, has an active feedback on being.

"The main issue of philosophy in relation to education write AD. Kopytov and V.N. Turchenko, is concretized as follows: is this sphere a reflection, that is, a consequence of material and industrial, socio-economic and political life, or is it the cause, the leading factor in its changes? Can the education system shape and form the future, or is it, doomed to the role of a "chip" of social reality, reflecting the changes taking place in a given society its achievements and vices? The authors suppose tha the answer "can not be reduced to a simple formal-logical "yes" or "no", but involves a deep, meaningful analysis. Then the question is transferred to the practical level: how, when and under what conditions education is determined by external factors, and when it acts as a factor and cause of changes in social life " [4, c.48].

Life convincingly shows that education not only reflects the objective reality, but increasingly affects its development. This was noted by A.A. Lyapunov, N.N. Moiseev, A. Peccei, R. Tagore, J. Galbraith, J. Delors and many other well-known scientists who hold different philosophical and ideological views. Today, with the improvement of educational systems, one way or another, all humanistic-minded people connect their hopes for a better future of humanity. However, the increasing role of education should not be exaggerated to the point of absurdity. Education can not be reduced to the dissemination of information. Education is, above all, a purposefully organized practical process for changing the surrounding social and natural environment and, at the same time, self-change of the people themselves.

\section{CONCLUSION}

Education becomes a socially negative factor when the development of scientific and professional knowledge is not associated with the moral education of students. Unfortunately, this situation has become typical in our country. The upbringing, which in the Russian, and in Soviet school went side by side with the education, firmly and sacredly, left the modern educational institutions due to liberalization. In postSoviet Russia, liberal "democrats" assumed not only ideological and patriotic upbringing, but the upbringing function in general unnecessary for the education system. In their opinion, the education system should only be engaged in teaching, which in principle is not correct.

In our opinion, this position is a delusion, since the role of upbringing in the education process is reduced to zero. Education in its content can have a different and even opposite directions in different historical types of society. Its tasks may include the formation of the widest range of personal qualities. However, in any society and at all times the core task of upbringing was and is the formation of such values as the Motherland, serving its people, the readiness of everyone, despite social differences, to protect the interests of the state, civil society, and consequently, their own interests.

At the same time, the influential role of education on the destiny of the country in general, and the fate of any particular individual, in particular is the unconditional categorical imperative and a good sign of our time. Precisely because of these circumstances, education can become not only an important factor in solving many of the pressing problems of mankind, but also the dominant factor in the formation of the person's life path, called destiny. "As fate becomes a factor of socialization and personal self-identification, man tend to know his destiny and consequently, to know of himself. Learning himself, a person learns society, calculates the most likely scenarios for the development of socio-cultural events, constructs his life path (individual route) and a model of destiny. The specificity of destiny is in the fact that this or that orientation on the concept of destiny is in close contact with the socio-cultural traditions of the peoples, the socio-cultural situation and the time in which the "man of society" exists [10, p.35]. That means that the contemporary "knowledge society" and socio-cultural time impact the content of objects of philosophical analysis - the destiny and the person itself.

A man, being a treasury of inexhaustible possibilities and potential abilities, at the same time is "not yet an established animal" with the incompleteness of human nature [9]. The issue of the incompleteness of human nature was further developed in the work "General Psychopathology." In this work K. Jaspers notes that no one has the right to force a man to change the life path, which he chose. A man himself, without someone else's indication, can change infinitely [11]. His abilities are unlimited, he himself is able to anticipate events and illuminate his way not by unrealistic impracticable, but by real attainable goals. Thus, he will be able to return to his ancestral beginnings, expressing human nature, will be able to control his destiny.

Thus, the scientific analysis carried out within the framework of our article allows us to conclude that the fate 
studies are presented in a fragmented manner and conceptual outlines of it are not formed. The problem of fate in the production plan is only indicated as a problem of human being in the sphere of education and society. A scientific solution to the problem is determined by a number of controversial points, the absence of large-scale and lengthy in the temporal, territorial and sociocultural continuums discussions, the insufficient elaboration of the established working definition of the term "human destiny". This, in turn, stimulates the need for a special study devoted to the problem of fate. The need for a comprehensive and systematic analysis of fate is comprehended and transformed into a problem of understanding the meaning of human destiny. However, the semantic understanding of human destiny and the notion of it in everyday life, as well as in various sciences, remain primitive and limited.

In the framework of traditional views, fate is interpreted as a representation of the predetermination and inevitability of events and actions in human life, as an all-encompassing, indisputable determination in a person's life that has no certainty and is absolutely unrelated to his behavior, like future - something that will happen, as the history of the existence of a certain kind of being. Meanwhile, the above-mentioned global analysts, in spite differences in their ideological and methodological views, hope that education can become not only an important factor in the solution of many vital problems of mankind, but also the "cornerstone" of the individual formation, the establishment of the life path called "fate of a man ".

\section{REFERENCES}

[1] Asmolov A.G. Psychoanalytic notes of functionary [Psihoanaliticheskie zapiski chinovnika], A.G. Asmolov. M.: Nachala-press, 1995. 46 p.

[2] Berger P. The construction of social reality. A Treatise on the Sociology of Knowledge [Konstruirovanie socialnoj realnosti. Traktat po sociologii znanija] P. Berger, T. Lukman. M.: Medium, 1995. 323 p.

[3] Davidov A. On the Problem of the Relation «Between» the Person and Society / A. Davidov // The Place of the Person in Social Life. M., 1991. P. 249

[4] Kopytov A.D. Methodology of the study of educational systems: Philosophy of Education. Innovative practice and management mechanisms: monograph [Metodologija issledovanija obrazovatel'nyh sistem: Filosofija obrazovanija. Innovacionnaja praktika i mehanizmy upravlenija: monografija] A.D. Kopytov, V.N. Turchenko. Tomsk: Tomskij CNTI, 2008. 238 p.

[5] Lunacharskij A.V. What is education? [Chto takoe obrazovanie?], A.V. Lunacharskij About national education [O narodnom obrazovanii] collection. M.: APN RSFSR, 1958. P.60-72.

[6] Manhejm K. The diagnosis of our time [Diagnoz nashego vremeni] K. Manhejm. M.: RAO A talking book [Govorjashhaja kniga], 2010. 744p.

[7] Marks K. Collected works in 50 v. [Sochinenija. V 50 t.] K. Marks, F. Jengels. 2-e ed. M.: Polit., 1955-1986. V.1, V.2, V.3, V.16, V.17, V.20, V.21, V.22, V.23.

[8] Mahlup F. Production and dissemination of knowledge in the United States [Proizvodstvo i rasprostranenie znanij v SshA] F. Mahlup. M.: Pub: Progress, 1966. 464 p.

[9] Nicshe F. Beyond Good and Evil. The Case of Wagner. Antichrist. Essay Homo. Human, All Too Human. Wicked wisdom. [Po tu storonu dobra i zla. Kazus Vagner. Antihrist. Esse Homo. Chelovecheskoe, slishkom chelovecheskoe. Zlaja mudrost] F. Nicshe. Minsk: Harvest, 2005. $879 \mathrm{p}$.

[10] Puzikov V.G. Sense of understanding of human life [Smysly ponimanija chelovecheskoj zhizni] V.G. Puzikov, Bulletin: Vestnik Omskogo gosudarstvennogo pedagogicheskogo universiteta. Gumanitarnye issledovanija. 2017. \#4 (17). P.34-36.

[11] Jaspers K. General psychopathology [Obshhaja psihopatologija] K. Jaspers. M.: Praktika, 1997. 288 p. 